\title{
Isolation and Biological Activity of the Triterpene B-Amyrin from the Aerial Plant Parts of Maesobotrya Barteri (Baill)
}

\section{Ogwuche $\mathrm{CE}^{1 *}$, Amupitan $\mathrm{JO}^{2}$, NdukwelG ${ }^{2}$ and Ayo RG}

${ }^{1}$ Department of Chemistry, Federal University of Petroleum Resources Effurun, Delta State, Nigeria

${ }^{2}$ Department of Chemistry, Ahmadu Bello University, Zaria, Kaduna State, Nigeria

${ }^{3}$ Department of Agricultural Division, Ahmadu Bello University, Zaria, Kaduna State, Nigeria

\begin{abstract}
Maesobotrya barteri (Baill), belonging to the family EUPHORBIACEAE, is a medicinal plant growing widely in tropical Africa. The Aerial plant parts of Maesobotrya barteri (Bail) were collected fresh from Orokam, Ogbadibo local Government of Benue State, Nigeria in July, 2013. Taxonomical identification was done by Mallam Musa Abdullahi at the Herbarium unit of Biological sciences Department, ABU, Zaria, Nigeria. Pulverized aerial parts of Maesobotrya barteri $(960 \mathrm{~g})$ was exhaustively extracted successively using petroleum ether, chloroform, ethyl acetate and methanol and concentrated in the rotary evaporator at $40^{\circ} \mathrm{C}$. The ethyl acetate fraction having the highest activity against test microbes from preliminary crude microbial screenings was subjected to phytochemical studies, antimicrobial analysis and column chromatography (CC). The column chromatography yielded fraction EN, which was further purified using preparative thin layer chromatography to give EN1. The structure of the isolated compound was established using 1-D NMR and 2-D NMR spectroscopic analysis and by direct comparism with data reported in literature was confirmed to be $\beta$-amyrin. The bioactivity of this compound was carried out using some clinical pathogens and the activity compared with standard drugs and this was found to be comparable with the standard drug.
\end{abstract}

Keywords: Maesobotrya barteri; Medicinal plant; Bioactivity; Ethylacetate extract; $\beta$-amyrin

\section{Introduction}

Maesobotrya $s p$ is a variety of flowering plant belonging to the family Phyllanthaceae or by some authors classified in Euphorbiaceae. The Euphorbiaceae plants are shrubs, trees, herbs or rarely lianas [1]. Plants of the Euphorbiaceae are known to be rich in terpenoids (69.5\%) [2].

In Nigeria, the species M. barteri is under-exploited although the tree is of both medicinal and nutritional importance [3]. Maesobotrya species are used medicinally in different regions in Africa [4]. It bears succulent black-purple fruits that are edible and stain the tongue. The nutritive values of the fruits and seeds have been studied in Southern Nigeria [5]. Thus, this study aims at validating the antimicrobial effects of the aerial plant parts of Maesobotrya barteri used in traditional medicine in Orokam town of Benue State, Nigeria, as well as potent compounds that can be used as precursors for synthetic drugs.

\section{Plant Material}

The aerial parts of Maesobotrya barteri were collected from Orokam in Ogbadibo local government area of Benue State in the month of July, 2013. They were properly identified at the herbarium, Department of Biological Sciences, Ahmadu Bello University, Zaria. The whole plant was sorted, air dried under shade, segregated and pulverized by mechanically pounding them using wooden mortar and pestle. The pulverized plant material was stored away from moisture.

\section{Extraction}

980.54g of the pulverized plant materials were carefully weighed and loaded into a Soxhlet extractor. It was extracted successively with Petroleum ether $\left(60-80^{\circ} \mathrm{C}\right)$, Chloroform, Ethyl acetate $\left(76-78^{\circ} \mathrm{C}\right)$ and Methanol by hot continuous percolation method in the Soxhlet apparatus for 72 hours respectively. Solvents used were those of JHD and general purpose reagentsThe extracts were concentrated in vacuo at $40^{\circ} \mathrm{C}$ using rotary evaporator and subjected to air drying to give dried crude extracts.

\section{Phytochemical Screening}

The crude ethyl acetate extract was subjected to phytochemical screening to test for saponins, tannins, steroids, flavonoids, alkaloids, cardiac glycosides, carbohydrates and tritepenes using standard techniques of plant secondary metabolites [6-8].

\section{Isolation}

The ethyl acetate extract was the most sensitive extract from the antimicrobial screening and was subjected to column chromatography (CC) for fractionation. Solvents used to run the column chromatograghy were sealed and are products JHD with $98 \%$ purity. Fifteen grams $(15 \mathrm{~g})$ of the extract was dissolved in ethyl acetate and preadsorbed on $10.0 \mathrm{~g}$ silica gel (qualikens 60-120 mesh). The dried pre-adsorbed extract was transferred to a mortar and ground to give a fine powder and was added at the uniform layer on top of the column. The petroleum ether descended on a horizontal line indicating that the column was well packed. A total of 105 fractions $(50 \mathrm{mls})$ each were initially collected using gradient elution with a solvent combination of petroleum ether and ethyl acetate, starting with $100 \%$ petroleum ether with an increasing polarity of $1 \%$ ethyl acetate. Similar fractions were pulled together based on monitoring from TLC. Fractions $\mathrm{F}_{20}-\mathrm{F}_{25}$ were pulled together at the ration of 8:2 and where subjected to further purification using Preparative thin layer chromatography to obtain a solid white amorphous substance which after several trails using different solvent combinations showed a single spot which was visible under the UV

*Corresponding author: Ogwuche CE, Department of Chemistry, Federal University of Petroleum Resources Effurun, Delta State, Nigeria, Tel: +2347037166612; E-mail: christogwu@gmail.com

Received August 30, 2014; Accepted October 25, 2014; Published October 27, 2014

Citation: Ogwuche CE, Amupitan JO, NdukwelG, Ayo RG (2014) Isolation and Biological Activity of the Triterpene B-Amyrin from the Aerial Plant Parts of Maesobotrya Barteri (Baill). Med chem 4: 729-728. doi:10.4172/21610444.1000221

Copyright: (c) 2014 Ogwuche CE, et al. This is an open-access article distributed under the terms of the Creative Commons Attribution License, which permits unrestricted use, distribution, and reproduction in any medium, provided the original author and source are credited. 
lamp and after spraying the TLC plate with $10 \% \mathrm{H}_{2} \mathrm{SO}_{4}$ and oven dried for 5 minutes at $60^{\circ} \mathrm{C}$. The solid white amorphous substance produced was insoluble in ethyl acetate or petroleum ether but soluble in chloroform [9-12].

\section{Results and Discussion}

From the preliminary antimicrobial screening of the crude aerial plant parts extracts of $M$. barteri, ethylacetate extract exhibited the highest activity against the test microbes used via their zones of inhibition. Therefore, an activity guided isolation was undertaken.

The results of the phytochemical screening of the ethyl acetate extracts of the aerial plant parts of Maesobotrya barteri reviewed the presences of carbohydrates, reducing sugars, cardiac glycosides, saponins, steroids, triterpenes, flavonoids and tannins (Table 1).

\section{Bioactivity of Compound $\mathrm{EN}_{1}$ Pure Isolate}

The antimicrobial activities of compound $\mathrm{EN}_{1}$ isolated from ethyl acetate extract of the aerial plant parts of M.barteri was examined and agar disc diffusion method [13] was employed for the determination of the antimicrobial activities. The pure compound was determined using some pathogenic microbes; the microbes were obtained from the department of Medical Microbiology Ahmadu Bello University Teaching- Hospital, Zaria, Nigeria.

The determination of minimum inhibitory concentration was carried out using the nutrient broth susceptibility assay prepared according to the manufacturer's instructions, as recommended by NCCLS [14]. Minimum inhibition McFarland turbidity standard scale number 0.5 was prepared to give turbid solution. Normal saline was prepared and was dispensed into test tube and the test microorganism was then inoculated into the normal saline, incubation was at $37^{\circ} \mathrm{C}$ for $6 \mathrm{hrs}$, dilution of the microorganism in the normal was performed until the turbidity marched that of the McFarland by visual comparison at this point the microorganism had a concentration of about $1.5 \times 10^{8} \mathrm{cfu} / \mathrm{ml}$.

Minimum Bactericidal and fungicidal concentration of compound EN1 was carried out to check whether the test microbes were killed or only their growth was inhibited. Mueller Hunton agars were prepared according to the manufacturer's instruction, as recommended by NCCLS [14]. They were boiled to dissolve and were sterilized at $121^{\circ} \mathrm{C}$ for 15 minutes, the media were cool to $45^{\circ} \mathrm{C}$ and the medium $(20 \mathrm{ml})$ was poured in to sterile Petri dishes, the plates were covered and allowed to cool and solidify. The contents of the MIC in the serial dilution was inoculated on to the media, the media were incubated at $37^{\circ} \mathrm{C}$ for $24 \mathrm{hrs}$ for the bacteria and at $30^{\circ} \mathrm{C}$ for 1-7 days for fungi, after which the plate were observed for colonies growth. The MBC/MFC was the plate with lowest concentrations of the extract without colony growth.

Table 2 shows the Zones of inhibition ( $\mathrm{mm}$ ) of the pure the compound

\begin{tabular}{|l|c|}
\hline Constituents & Ethylacetate extract \\
\hline Carbohydrate & + \\
\hline Saponnins & + \\
\hline Flavonoid & + \\
\hline Tannins & + \\
\hline Cardiac glycosides & + \\
\hline Steroids & + \\
\hline Triterpenes & - \\
\hline Anthraquinone & - \\
\hline Alkaloids & \\
\hline
\end{tabular}

KEY: + = Present, - = Absent; NT= Not tested.

Table 1: Phytochemical constituents of Ethylacetate extract Aerial plant parts of M. barteri.

\begin{tabular}{|l|c|c|c|c|}
\hline Test Organism & $\begin{array}{c}\text { Compound } \\
\text { EN }_{\text {1 }}\end{array}$ & & Fluconazole & Fulcin \\
\hline Staphylococus aureus & 32 & 37 & 0 & 0 \\
\hline Streptococuspyogenes & 30 & 35 & 0 & 0 \\
\hline Streptococcus feacalis & 32 & 39 & 0 & 0 \\
\hline Corynebacteruimulcerans & 0 & 32 & 0 & 0 \\
\hline Escherichia coli & 32 & 38 & 0 & 0 \\
\hline Klebsiella pneumonia & 32 & 40 & 0 & 0 \\
\hline Salmonella typhi & 30 & 42 & 0 & 0 \\
\hline Shigella dysenteriae & 30 & 40 & 0 & 0 \\
\hline Candida albicans & 0 & 0 & 35 & 0 \\
\hline Candida krusei & 27 & 0 & 37 & 0 \\
\hline Candida tropicalis & 0 & 0 & 32 & 0 \\
\hline Candida stellatoidea & 25 & 0 & 37 & 0 \\
\hline Microsporumsp & 26 & 0 & 0 & 38 \\
\hline Aspargillus fumigates & 0 & 0 & 0 & 32 \\
\hline Aspargillusnigre & 0 & 0 & 0 & 34 \\
\hline Trichophytonrutarum & 28 & 0 & 0 & 38 \\
\hline
\end{tabular}

Table 2: Zone of inhibition of Compound $\mathrm{EN}_{1}$ against the test microorganism.

$\mathrm{EN}_{1}$ from the ethyl acetate fraction which showed remarkable activity against twelve of the sixteen organisms tested. Compound $\mathrm{EN}_{1}$ could not inhibit the growth of Corynebacterium ulcerans, Candida albicans, Candida tropicalis, Aspergillus fumigates, Aspergillus nigre. The various minimum inhibitory concentration (MIC) and minimum Bacteriocidal concentration and fungicidal concentration (MBC/MFC) for the different microbes are as shown in Tables and the bioactivity of the aerial plant parts of $M$. barteri is comparable to the drugs Ciprofloxacin, Fluconazole and Fulcin used as positive controls.

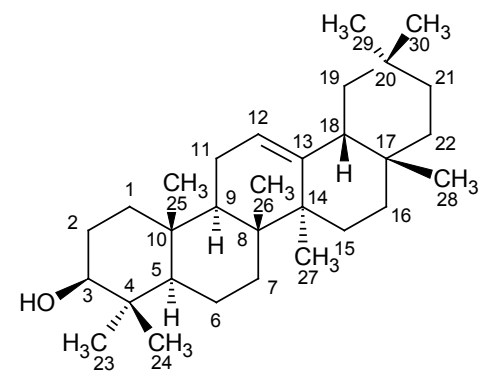

EN1- $\left(\mathrm{C}_{30} \mathrm{H}_{50} \mathrm{O}, 426.7 \mathrm{~g} / \mathrm{mol}\right)$

Name: $\beta$-Amyrin or $\beta$-Amyrenol

Tables 2 and 3 show the activity of the compound $\mathrm{EN}_{1}$ which the spectroscopic analysis was proposed to be a $\beta$-Amyrin or $\beta$-Amyrenol, $\left(\mathrm{C}_{30} \mathrm{H}_{50} \mathrm{O}, 426.7 \mathrm{~g} / \mathrm{mol}\right)$. Antimicrobial screening reported from other natural products has also confirmed the microbial properties of $\beta$-Amyrin. $\beta$-Amyrin was isolated from Ardisiaelliptica [9], a medicinal plant used for alleviating chest pain, fever, liver poisoning and parturition complications. It was found that $\beta$-Amyrin was six times as active as aspirin in inhibiting platelets aggregation. $\beta$-amyrin was isolated for the first time from Laurenciamicrocladia, marine algae distributed widely in Egypt found to have antibacterial activity against Staphylococcus aureus, Bacillus subtilis, Salmonella typhi, Escherichia coli, and Pseudomonas aeurginosa [10].

\section{Spectra Results}

The structure of compound $\mathrm{EN}_{1}$ was elucidated using Nuclear Magnetic Resonance Spectroscopy(NMR), 1-DNMR and 2-DNMR and also by comparing the obtained data with already existing literature. The results obtained are as shown in the table 4.

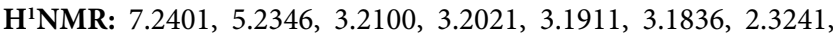




\begin{tabular}{|c|c|c|c|c|c|}
\hline $\begin{array}{c}\text { Test } \\
\text { Organisms }\end{array}$ & Concentration & $50 \mu \mathrm{g} / \mathrm{ml}$ & $25 \mu \mathrm{gg} / \mathrm{ml}$ & $\begin{array}{c}12.5 \mathrm{\mu g} / \\
\mathrm{ml}\end{array}$ & $6.2 \mathrm{\mu g} / \mathrm{ml}$ \\
\hline $\begin{array}{c}\text { Staphylococus } \\
\text { Aureus }\end{array}$ & - & - & - & $0^{*}$ & + \\
\hline $\begin{array}{c}\text { Streptococus } \\
\text { Pyogenes }\end{array}$ & - & - & $0^{*}$ & + & + \\
\hline $\begin{array}{c}\text { Streptococcus } \\
\text { Feacalis }\end{array}$ & - & - & - & $0^{*}$ & + \\
\hline $\begin{array}{c}\text { Escherichia } \\
\text { Coli }\end{array}$ & - & - & - & $0^{*}$ & + \\
\hline $\begin{array}{c}\text { Klebsiella } \\
\text { Pneumonia }\end{array}$ & - & - & - & $0^{*}$ & + \\
\hline $\begin{array}{c}\text { Salmonella } \\
\text { Typhi }\end{array}$ & - & - & - & $0^{*}$ & + \\
\hline $\begin{array}{c}\text { Shigella } \\
\text { Dysenteria }\end{array}$ & - & - & - & $0^{*}$ & + \\
\hline $\begin{array}{c}\text { Candida } \\
\text { Krusei }\end{array}$ & - & - & $0^{*}$ & + & + \\
\hline $\begin{array}{c}\text { Candida } \\
\text { Stellatoidea }\end{array}$ & - & - & $0^{*}$ & + & + \\
\hline $\begin{array}{c}\text { Microsporum } \\
\text { Sp }\end{array}$ & - & - & $0^{*}$ & + & + \\
\hline $\begin{array}{c}\text { Trichophyton } \\
\text { Rubrum }\end{array}$ & - & - & $0^{*}$ & + & + \\
\hline
\end{tabular}

KEY: $-=$ No turbidity (No growth), $0^{*}=$ MIC,

$+=$ Turbid (Growth)

Table 3a: Minimum Inhibition Concentration (MIC).

\begin{tabular}{|c|c|c|c|c|c|c|}
\hline Test Organisms & Concentration & $\begin{array}{c}50 \mu \mathrm{g} / \\
\mathrm{ml}\end{array}$ & $\begin{array}{c}25 \mu \mathrm{g} / \\
\mathrm{ml}\end{array}$ & $\begin{array}{c}12.5 \\
\mu \mathrm{g} / \mathrm{ml}\end{array}$ & $\begin{array}{c}6.2 \mu \mathrm{g} / \\
\mathrm{ml}\end{array}$ & $3.12 \mu \mathrm{g} / \mathrm{ml}$ \\
\hline $\begin{array}{c}\text { Staphylococus } \\
\text { aureus }\end{array}$ & - & - & $0^{*}$ & + & + & + \\
\hline $\begin{array}{c}\text { Streptococus } \\
\text { pyogenes }\end{array}$ & - & - & $0^{*}$ & + & + & + \\
\hline $\begin{array}{l}\text { Streptococcus } \\
\text { feacalis }\end{array}$ & - & - & $0^{*}$ & + & + & + \\
\hline Escherichia coli & - & - & $0^{*}$ & + & + & + \\
\hline $\begin{array}{l}\text { Klebsiella } \\
\text { pneumonia }\end{array}$ & - & - & - & $0^{*}$ & + & + \\
\hline Salmonella typhi & - & - & $0^{*}$ & + & + & + \\
\hline $\begin{array}{c}\text { Shigella } \\
\text { dysenteria }\end{array}$ & - & - & $0^{*}$ & + & + & + \\
\hline Candida krusei & - & - & O* & + & + & + \\
\hline $\begin{array}{c}\text { Candida } \\
\text { stellatoidea }\end{array}$ & - & $0^{*}$ & + & + & + & + \\
\hline Microsporum $s p$ & - & $0^{*}$ & + & + & + & + \\
\hline $\begin{array}{l}\text { Trichophyton } \\
\text { rubrum }\end{array}$ & - & - & $0^{*}$ & + & + & + \\
\hline
\end{tabular}

KEY: $-=$ No turbidity (No growth), $\mathrm{o}^{*}=$ MBC/MFC

$+=$ Turbid (Growth)

Table 3b: Minimum Bactericidal Concentration and Minimum Fungicidal Concentration (MBC/MFC)

$2.1768,2.1585,2.0742,2.0181,2.0023,1.9942,1.9793,1.9727$, $1.9067,1.9012,1.8923,1.8865,1.8621,1.8455,1.8379,1.8227,1.7276$, $1.7067,1.6857,1.6669,1.6529,1.6353,1.6302,1.6127,1.5952,1.5890$, $1.5669,1.5463,1.5230,1.4987,1.4836,1.4667,1.4579,1.4402,1.4276,1.373$ $0,1.3429,1.3195,1.2990,1.2780,1.2630,1.2329,1.1813,1.1514,1.1169$, $1.0870,1.0639,1.0316,1.0195,0.9989,0.9759,0.9681,0.9404,0.9322$, $0.9217,0.9088,0.8927,0.8841,0.8680,0.8591,0.84500 .8341$

${ }^{13}$ CNMR: $137.9624,125.9002,79.0731,77.2169,77.0054,76.7938$, 55.2568, 52.7408, 47.9239, 47.5759,42.0388, 39.5194, 39.0811, 38.8495, $38.7715,38.6441,37.0200,36.7105,33.0001,30.6267,29.6969,29.3557$, $28.1492,28.0359,27.2530,24.2027,23.5770,23.3098,21.1608$, $18.3150,17.0954,16.9846,15.5986,15.4777$.

The ${ }^{13} \mathrm{C}$ NMR spectrum (Figures $1-7$ ) showed thirty (30) major

\begin{tabular}{|c|c|c|c|}
\hline $\begin{array}{l}\text { Carbon } \\
\text { Position }\end{array}$ & $\begin{array}{c}\delta^{13} \mathrm{CNM} \text { ठppm } \\
\beta \text {-amyrin, } \\
\text { Experimental }\end{array}$ & $\begin{array}{c}\delta^{13} \mathrm{CNMR} \delta p p m \\
\beta \text {-amyrin, Literature } \\
{[12]}\end{array}$ & $\begin{array}{c}\delta^{13} \mathrm{CNMR} \text { ठppm } \\
\beta \text {-amyrin, } \\
\text { Literature [11] }\end{array}$ \\
\hline 1 & 38.8495 & 38.7 & 37.3 \\
\hline 2 & 27.2530 & 27.2 & 28.28 \\
\hline 3 & 79.0731 & 79.3 & 71.85 \\
\hline 4 & 38.7715 & 38.5 & 37.30 \\
\hline 5 & 55.2568 & 55.1 & 36.81 \\
\hline 6 & 18.3150 & 18.6 & 21.12 \\
\hline 7 & 38.6441 & 32.4 & 42.35 \\
\hline 8 & 39.5194 & 39.8 & 45.90 \\
\hline 9 & 47.9239 & 47.6 & 50.18 \\
\hline 10 & 36.7105 & 36.9 & 36.55 \\
\hline 11 & 23.5770 & 23.6 & 24.33 \\
\hline 12 & 125.9002 & 121.7 & 121.70 \\
\hline 13 & 137.9624 & 145.2 & 140.81 \\
\hline 14 & 42.0388 & 41.7 & 44.36 \\
\hline 15 & 29.3557 & 26.2 & 26.13 \\
\hline 16 & 21.1608 & 26.1 & 23.11 \\
\hline 17 & 29.6969 & 32.6 & 48.48 \\
\hline 18 & 47.5759 & 47.2 & 45.89 \\
\hline 19 & 39.0811 & 46.8 & 39.82 \\
\hline 20 & 30.6267 & 31.0 & 36.49 \\
\hline 21 & 33.0001 & 34.7 & 34.00 \\
\hline 22 & 37.0200 & 37.1 & 31.71 \\
\hline 23 & 28.0359 & 28.0 & 29.3 \\
\hline 24 & 15.5986 & 15.4 & 19.84 \\
\hline 25 & 15.4777 & 15.4 & 19.10 \\
\hline 26 & 16.9846 & 16.8 & 18.90 \\
\hline 27 & 24.2027 & 25.9 & 18.30 \\
\hline 28 & 17.0954 & 28.4 & 19.20 \\
\hline 29 & 28.1492 & 33.8 & 36.18 \\
\hline 30 & 23.3098 & 23.7 & 19.42 \\
\hline
\end{tabular}

Table 4: Comparison of ${ }^{13} \mathrm{C}$ NMR spectrum data of $\beta$-amyrin Obtained from the Aerial parts of $M$. barteri with literature

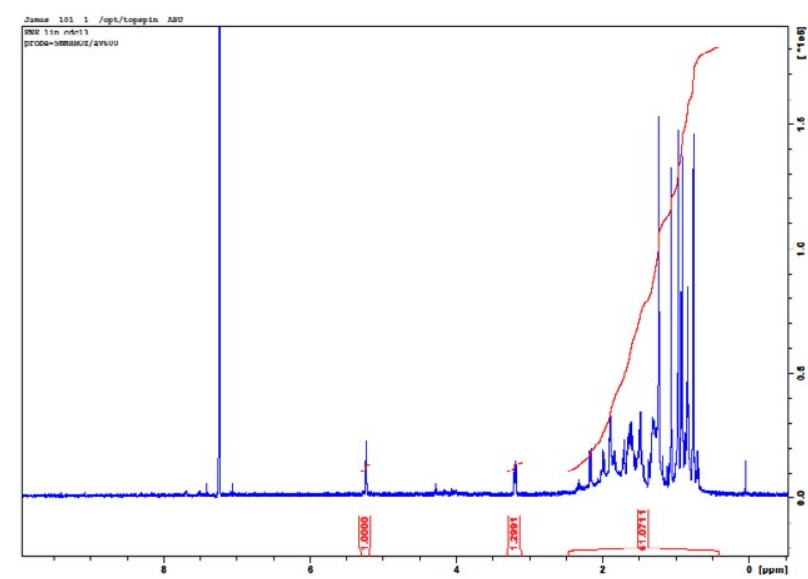

Figure 1: ${ }^{1} \mathrm{HNMR}$.

recognizable carbon signals, eight methyl groups at $\delta 37.0200$ (C22), 28.0359 (C-23), 15.5986 (C-24), 15.4777(C-25), 16.9846 (C-26), 24.2027 (C-27), 17.0954(C-28), 28.1492(C-29), 23.3098 (C-30) and a secondary hydroxyl bearing carbon 79.0731 at (C-3). It also showed some recognizable signals at $\delta 125.9002$ and $137.9624 \mathrm{ppm}$ which is assignable to the double bond at C-12 and C-13. In addition, ten methylene groups, eight methyl groups, six quaternary carbons atoms 


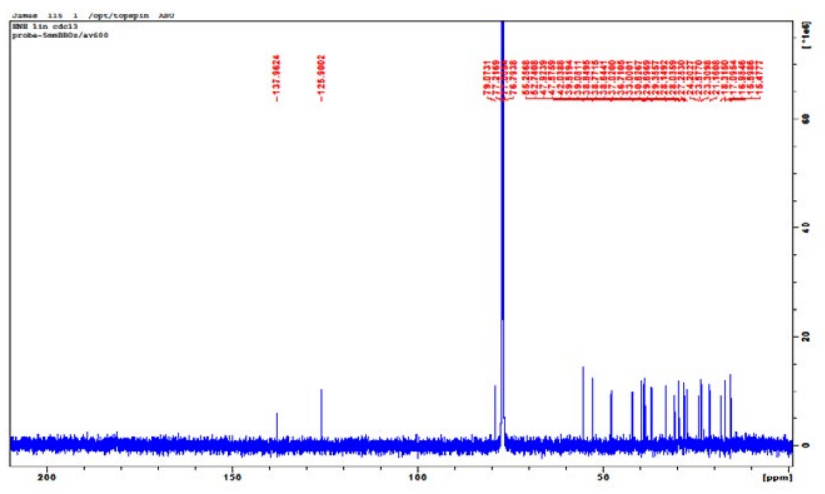

Figure $2:{ }^{13} \mathrm{C} N M R$

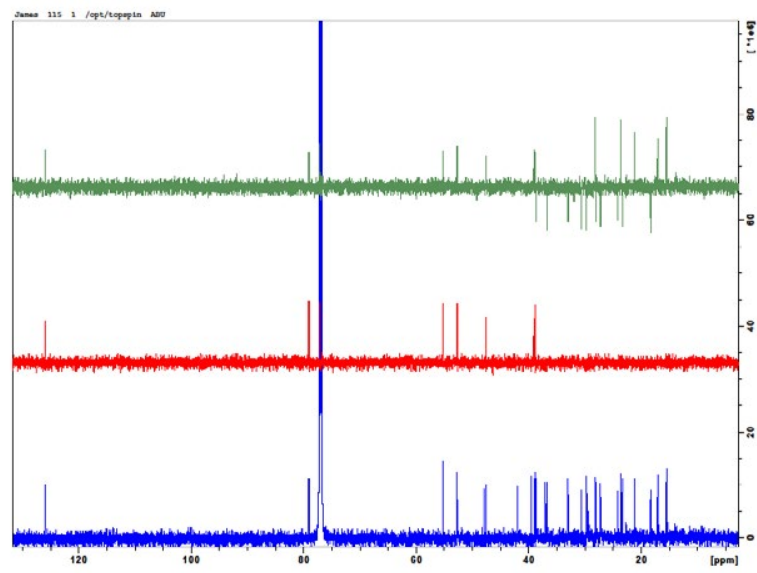

Figure 3: DEPT.

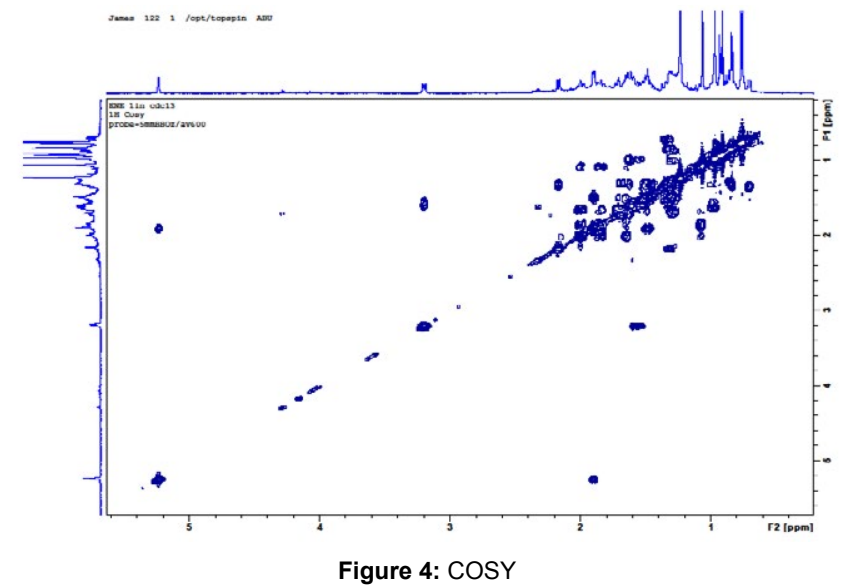

from DEPT experiment were observed. The chemical shift at $\delta 137.962$, 125.9002 which are C-12 and C-13 and the consistent flow of methyl groups from C-23 to C-30 were characteristic peaks for a $\beta$ - Amyrin type of skeleton [11] and [12].

${ }^{1} \mathrm{HNMR},{ }^{13} \mathrm{C}$ NMR and DEPTH spectra of the proposed compound $\beta$-amyrin.

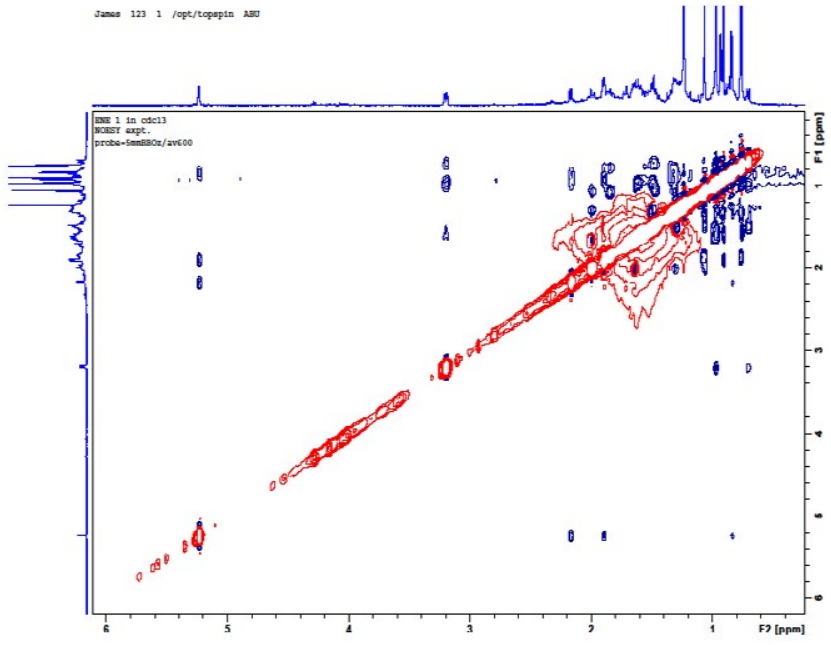

Figure 5: NOESY

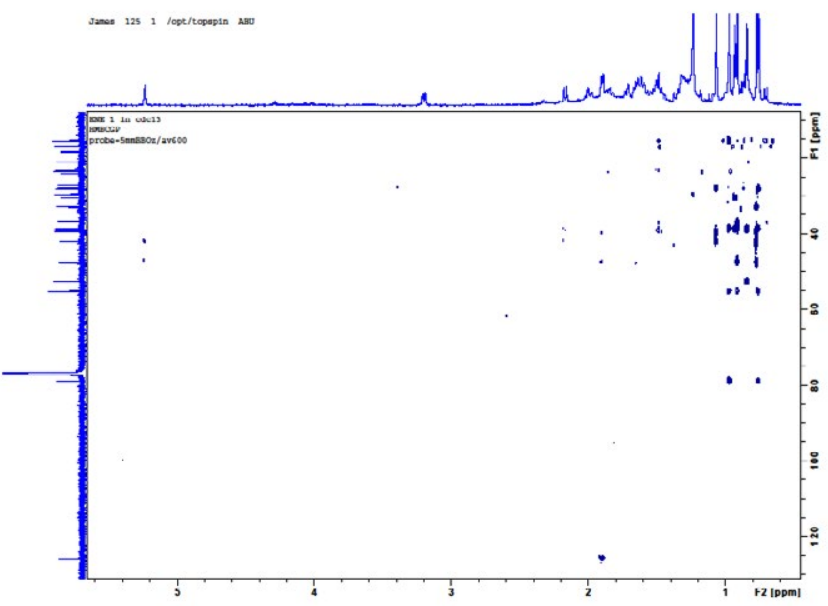

Figure 6: HMBC

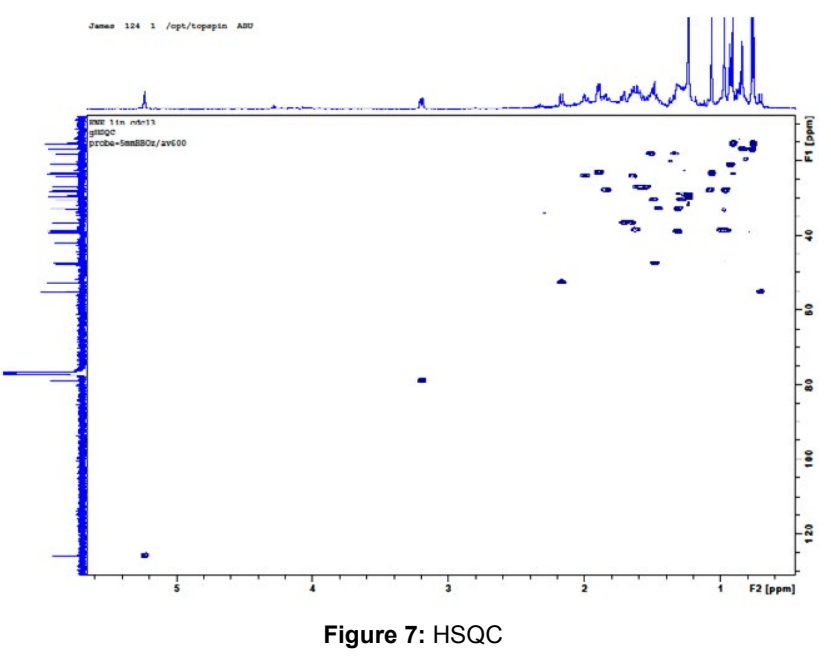

\section{Conclusion}

The isolation of $\beta$-Amyrin from the aerial plant parts of $M$. 
barteri, whose bioactivity was established from this work by its zone of inhibition, is comparable to the drugs of Ciprofloxacin, Fluconazole and Fulcin. This justifies why the plant really serves as a general purpose antibiotic in traditional medicine in our society. The preliminary phytochemical screening also shows that the ethyl acetate extract contains other classes of compounds that can be further isolated and tested for microbial activities and this can lead to chains of discoveries as the quest of precursors for modern drugs are continually on course.

\section{Acknowledgement}

Authors thank Professor Francis Oluwole Shode of Department of Chemistry, University of Kwa-zulunatal, Durban, South Africa and Dr Habila James of the Department of Chemistry, Ahmadu Bello University, Zaria, Nigeria for helping in carrying out the spectroscopic analysis of the sample. We also like to acknowledge the Department of Chemistry, Ahmadu Bello University, Zaria- Nigeria, for providing an enabling laboratory environment for this research work.

\section{References}

1. Pandey BP (2006) A textbook of Botany: Angiosperms, Taxonomy, Anatomy, Embryology (including tissue culture) and Economic Botany, S Chand and Co., Ltd., Ram Nagar, New Delhi.

2. Ntie-Kang F, Mbah JA, Mbaze LM, Lifongo LL, Scharfe M, et al. (2013) Cam MedNP: Building the Cameroonian 3D structural natural products database for virtual screening. BMC Complement Altern Med 13:88

3. Ogbuagu MN, Agu B (2008) Fruit nutritive composition of Maesobotryabarteri, an under-exploited tropical African tree. Fruits 63: 357-361

4. Okwu DE, Ekeke O (2003) Phytochemical screening and mineral composition of chewing sticks in South Eastern Nigeria. Global journal of pure and applied sciences 9: 235-238
5. Uduak AE, Kola KA (2010) Antimicrobial activities of some euphorbiaceae plants used in the traditional medicine of akwaibom state of nigeria. Ethnobotanical Leaflets 14: 654-64.

6. Trease GE, Evans WC (2002)Pharmacognosy 15th Ed, Saunders.

7. Sofowora A (1993) Medicinal plants and traditional medicine in Africa, Spectrum books Ltd., Ibadan, Nigeria.

8. Harbone JB(1984) Phytochemical methods. Chapman and Hall, London 89-131.

9. Ching J, Chua TK, Chin LC, Lau AJ, Pang YK, et al. (2010) ß-Amyrin from Ardisiaelliptica. Thunb is mor potent than aspirin in inhibiting collagen induced platelet aggregation. Indian J Exp Biol 48: 275-279.

10. Neveen AR, Nouf MA, Ali AA, Ibraheem BM, Monerah RA, et al. (2003) Antibacterial $ß$-amyrin isolated from Laurenciamicrocladia. Arabian journal of chemistry In press.

11. Manal A, Ahmad D, Suleiman AK (2009) Isolation and Identification of Anti-Ulcer Components from Anchusa Strigosa Root. Jordan journal of pharmaceutical sciences 2: 131.

12. Hernández LV, Palazon J, Navarro-OcañaA (2012) The Pentacyclic Triterpenesa, ß-amyrins: A Review of Sources and Biological Activities. InTech 978-953-51-0296-0.

13. Bauer AW, Kirby WM, Sherris JC, Turck M (1966) Antibiotic susceptibility testing by a standardized single disk method. Am J Clin Pathol 45: 493-496.

14. Farraro MJ, Craig WA, Dudley MN, Eliopoulos GM, Hecht DW, et al. (2000) Performance Standards for Antimicrobial Disk Susceptibility Tests, Approved Standard M2-A7, 7th ed.; National Committee for Clinical Laboratory Standards: Wayne, PA, USA1-26. 